\title{
Introduction
}

\section{Fictional representations of multilingualism and translation}

\author{
Dirk Delabastita \& Rainier Grutman \\ University of Namur \& University of Ottawa
}

\section{The road less travelled}

Back in the 1980s, when one of us two started looking into literary bilingualism, scholars working on the topic often felt obliged to justify their interest in such an unconventional domain of study. Bilingual writers and multilingual texts were still very much frowned upon, being freak-like exceptions to the unwritten rule of monolingualism in the literary realm, notwithstanding the (by now well-documented) fact that every century and every genre has seen its share of language-related experiments. Even while paying homage to Leonard Forster's classic series of lectures on The Poet's Tongues (1970), a comparatist of the stature of Claudio Guillén (1985: 328), the first critic ever to include multilingualism as a legitimate subject in a handbook of comparative literature, could not resist forestalling his readers' reactions: "No se me oculta una posible objeción: que muchos de estos autores eran de segunda fila". Nor could he help downplaying multilingual writing by the not-quite-second-rate authors, such as John Milton, Stefan George and Rainer Maria Rilke, whom he included in his survey (327-344). Milton, he argued, would have been equally famous had he not written in Latin, Greek and Italian.

In today's world, talk of multilingualism no longer raises eyebrows but is seen, quite matter-of-factly, as a sign of the times. ${ }^{1}$ Whether this is due to Deleuze's and Guattari's work on the 'deterritorializing' powers of language, or Bakhtin's forceful critique of 'monologic' and 'monoglossic' tendencies in Western thought, or the 'hybrid' character of postcolonial texts and cultures, or all of the above, the times they are indeed a-changin'. Translation studies can justifiably be said to have been in the forefront of this paradigm shift. As early as the 1970s, when structuralism was in full swing and linguistics' towering presence in the humanities still went largely unquestioned, some translation scholars started to grow frustrated with purely linguistic models, and isolated calls were made for a much-needed change of perspective, one which (much) later would become known as a "cultural turn" (Bassnett \& Lefevere 1990).

Let us briefly return to those days, when semiotics and linguistics were the flavour of the month. In 1976, linguists of the calibre of Eugenio Coseriu, Mario Wandruszka and Wolfram Wilss gathered in Stockholm for a large symposium on translation sponsored by the Nobel Foundation. Regretting the absence of Georges Mounin, organiser Bertil Malmberg (1978: 11) pointed out the "caractère éminemment linguistique de la théorie 
de la traduction et l'intérêt qu'il y a à confronter l'analyse du langage et 'l'activité traduisante". Coseriu (1978: 17) argued that "die Übersetzungstheorie eigentlich eine Sektion der Textlinguistik sein müsste", while Wilss (1978: 51) welcomed the evolution from a traditional, prescriptive, philosophically-inclined theory of translation, to an "übersetzungslinguistischen Fachwissenschaft". Some conference participants did suggest a broadening of horizons, but the question remains whether their calls were heard. A barely 35-year-old José Lambert, for instance, underscored the "cultural necessity of translation", and stated in no uncertain terms that "la traduction doit être considérée non pas comme une question purement linguistique, mais comme une question culturelle" (in the long discussion following Denison 1978: 338-339). Since this is also the underlying premise of the present collection of articles, we would like to present it to our former teacher and long-time compagnon de route José, now on the eve of his retirement from the University of Leuven, as a token of our appreciation and friendship.

The final paper at the 1976 Nobel symposium was delivered by Norman Denison, a veteran sociolinguist equally conversant with Romance and Germanic languages, whose expertise lies in the study of polyglossic speech repertoires developed by communities inhabiting the contact zone formed by Austria, Northern Italy and Slovenia. The title of his intervention in Stockholm, "On Plurilingualism and Translation", bears more than a passing resemblance to the ideas laid out in this thematic issue of Linguistica Antverpiensia NS, which is why we would like to dwell on it a bit longer. Denison frames the relationship between the two possible outcomes of language contact (i.e. translation and multilingualism) in an unusual yet stimulating fashion. Whilst popular belief would gladly "consider translation a more natural and necessary human undertaking than the active, functional plurilingualism of whole communities in daily life", he thought-provokingly argues, "it turns out that where groups of people find themselves obliged to participate in heterolinguistic communication networks, functional plurilingualism is the solution [most] often adopted" (Denison 1978: 313). Translation (or its forefather and cousin, interpretation), ${ }^{2}$ he claims, only tends to occur in two types of cases, the first of which being those instances "where individuals and groups from mutually remote parts of a continuum lacking a lingua franca need to interact" (ibid.). The fact that we in the Western world, where communication typically has to bridge long distances and involves increasingly sophisticated technology, consider this to be the default-situation, does not imply that it actually is: Denison quotes examples from the Amazon area, as well as from Africa and New Guinea, where adult multilingual competence is the rule, not the exception. Likewise, he goes on to say, "translation is seldom necessary for purely informative needs", but tends to intervene for "considerations other than the straightforward communication of information" (ibid.). Many of those considerations could be called tactical, in that translation is often invoked "for reasons of ritual, dignity, civil rights or [even] time-gaining" (314), by participants in a commu- 
nication situation who actually $d o$ have a passive understanding of what was said in the other language, but prefer to have it repeated in their own. Communication of information alone, then, cannot account for the use of Gaelic place names in Wales, or for the presence of English road signs (including important ones like SLOW and DANGER) in Pakistan, or for the use of English in advertisements in many non-English-speaking countries (314-315). In those and many more instances, translation is not carried out in order to "re-encode basic semantic information for the benefit of a monolingual", but rather "to convey a different set of social presuppositions" (316).

This might be all the more true in literature, where the mere communication of semantic information can hardly be said to be the main issue. More often than not, something else is at stake when the decision is made to (re)translate a text of literary and cultural significance. In the early $1990 \mathrm{~s}$, for instance, Shakespeare's Macbeth was translated not once but twice into a language whose speakers have direct access to the original English play, namely Scots. Any concern about the Scottish audience's understanding of Shakespeare is at best a pretext for the politically inspired project of lifting Scots above the status of a 'dialect' or worse, a bastard offshoot of English, and making it into a 'real' literary language that accommodates Shakespeare's tragedy as effectively as English, indeed finally giving Shakespeare's Scottish heroes their true voices! Such translations are more to do with nationalistic cultural policies than with the decoding and recoding of linguistically opaque meanings. Annie Brisset (1996) discusses comparable rewritings of plays by Corneille and Molière in French Canada. Similarly, when Mexican-American Ilan Stavans (2003: 253-258) was recently provoked into producing a Spanglish version of the opening lines of Cervantes' Quixote, this gesture caused quite a stir, not least in America's Latino communities. Whereas some language purists simply did not think the mixed speech of illiterate Latinos was 'worthy' of such an endeavour, other critics pointed out that those educated enough to be able to write in Spanglish should just stick with the original Castilian text. This reaction misses the point that Stavans was trying to make, though. He did not intend his translation to act as a replacement for the original, but rather as proof of the stylistic and indeed literary possibilities Spanglish offered to whoever was willing to explore them. As Marco Kunz (in this volume) reminds us, the reader most likely to derive pleasure from Stavans' initiative, actually is s/he who compares Cervantes' early $17^{\text {th }}$-century text with its early $21^{\text {st }}$-century reincarnation.

\section{Fictional representations of language contact in time and space}

The increasing use of either translation or other languages (that need not be entirely 'foreign', for the reasons given by Denison) as a device in fictional texts does more than just draw the reader's attention to their texture and 
technique (this latter point was made a long time ago by the Russian formalists in their classical essays on 'foregrounding'). Crucially, it also provides a comment about our socio-cultural values and the state of the world we live in. In that respect, fictional representations of multilingualism on the one hand, and of translation on the other, ultimately lead us back to a common reality, that is, if we understand 'translation' not just as an abstract or 'technical' operation between words and sentences, but as cultural events occurring, or significantly not occurring, between people and societies in the real world. This viewpoint entails a radical questioning of traditional divisions between disciplines such as history, sociology, linguistics, translation studies, and literary studies (to mention but those five). By the same token, the area which could theoretically be meant to be covered by the present volume becomes spectacularly large. Indeed, if we want to study all cases where real-world multilingualism turns out to be toned down or suppressed in its fictional representation (for whatever reason), in addition to all cases where multilingualism, coupled or not with translation, duly finds a place in fictional representations, we end up studying more or less all of recorded human history. Quite a research programme!

The articles in the present collection are more modest in scope. With some exceptions, they draw upon fairly recent or even contemporary material, which is perhaps due to the fact that reflections on and portrayals of language contact are front and centre in contemporary literature, be it from Africa or Asia, North or Latin America, Western or Eastern Europe. This is not to say, of course, that literary multilingualism, in its multifarious forms, is an entirely new phenomenon. As Leonard Forster (1970) amply demonstrated in his aforementioned lectures, the Middle Ages, the Renaissance, and the Baroque era were all extremely fertile breedinggrounds for experiments in multilingual writing. Nor does it necessarily imply that language contact has exploded exponentially - it might well have, but accurate figures are difficult to obtain and even more difficult to assess. There is reason to believe, for instance, that the vast migration movement which ended more or less a century ago was more significant, in sheer numbers at least, than anything we witness today. Between 1804 and 1927 (the time it took the world's total population to go from one to two billion), about fifty million Europeans left their continent for overseas destinations. To reach similar proportions today, in a world of more than six billion people, migration numbers would have to be more than three times as high. The main difference between then and now would seem to be less a matter of facts and figures than a question of attitude: more and more Western academics, living in centralized cultures where the monopoly of communication is traditionally held by monolingual media, are noticing the real multilingualism lying beneath the surface of official, often State-induced, monolingualism. In what follows, we too will try once again to scratch that surface and lay bare some of the assumptions and contradictions underlying commonly held views on language and languages. 
If we were to put the following articles in chronological order, Victoria Ríos-Castaño's work on the role played by Native interpreters in the Spanish conquest of the Americas would become our first entry, followed by Fernando Toda's look at the political motivations of multilingualism in Walter Scott's Waverley novels, and Christine Lombez's appraisal of pseudo-translations in $19^{\text {th }}$-century France. The other papers all focus on more recent material.

Several contributions specifically address the theme of the interpreter as linguistic and cultural go-between. Ilse Logie and Hildegard Vermeiren study the dangers this ambiguous position potentially entails in fiction set in Latin-America, while Raymond Mopoho and Katrien Lievois tackle the way they are evoked in writing from the former French colonies in Africa. The fictional figure of the translator also receives considerable attention and interest. It is dealt with either in more general terms (see Iulia Mihalache's paper) or in specific cultural contexts: Judy Wakabayashi concentrates on Japanese fiction, Brian James Baer on Russian detective novels, Marella Feltrin-Morris on a recent Italian best-seller, and Beverley Curran on postcolonial writing from Canada, Australia, and the United States. In her article, Jean Anderson adds a twist to this perspective by asking herself how fictional translators fared in novels by authors who were translators themselves.

Yet other contributors concentrate on textual aspects of multilingualism and translation. Juliette Taylor provides us with fascinating insights into polyglot puns and "mistranslation" in Nabokov, while Maria Brunner and Marco Kunz draw our attention to the complex mechanisms involved in the fictionalization of socially stigmatized speech styles in migrant literature (Gastarbeiterdeutsch and Spanglish, respectively). The latter relates this question to matters of reader response, which is a central issue in Carolina Amador Moreno's paper on bilingual writing by Javier Marías and Antonio Muñoz Molina. Two articles boldly go beyond printed media: Tessa Dwyer explores the poetic and ideological potential of intercultural (mis)communication in her essay on Sofia Coppola's movie Lost in Translation and the polyglot film genre, and Roberto Valdeón probes the pitfalls of translating foreignisms in the American situation comedy Frasier.

\section{An open concept of multilingualism}

The simplest possible definition of a multilingual text would be to say that such a text is worded in different languages, but that still begs the fundamental question of how one should understand the concept of 'language'. We favour a very open and flexible concept which acknowledges not only the 'official' taxonomy of languages but also the incredible range of subtypes and varieties existing within the various officially recognised languages, and indeed sometimes cutting across and challenging our neat linguistic typologies (e.g. the linguistic interference in the language of immigrant populations 
discussed by Brunner and Kunz). If habit and convenience may well continue to prop up the conventional distinction between 'languages' and 'language varieties', we would be well advised to keep in mind how shifty and problematic the dividing line really is!

Such an open concept of language may be recommended for the sake of text-internal analysis. Indeed, to the literary critic chiefly concerned with text interpretation, it matters relatively little in itself whether it is 'national', 'dead' or 'artificial' languages, slang, dialects, sociolects, or idiolects, that make up the multilingual sequences. What matters more is their textual interplay. From this angle, all of these are comparable inasmuch as everything depends on the ways in which the 'other' languages are embedded in the overall text and made to interact with each other and with the text's 'main' language. How is the verbal space of the text divided between the different languages? How does the text linguistically orchestrate the various character and narrative voices? If different languages are made to resonate at the various textual, paratextual and intertextual levels (prefaces, citations, annotations, metafictional passages, etc.) that make up the text, how and why is that done? What is the function or effect of all this?

In principle, texts can either give equal prominence to two (or more) languages, or merely add a more or less liberal sprinkling of other languages to a dominant language clearly identified as their central axis. The latter solution is much more commonly encountered, with the actual quantity of foregrounded linguistic material varying widely. For a Romantic poet like Gérard de Nerval, a short Spanish title (El desdichado) was enough to conjure up exotic landscapes and valiant knights. The writer of fiction, on the other hand, may want to either incorporate larger foreign language samples - taking up entire paragraphs or even pages, as in Tolstoy's War and Peace and Sterne's Tristram Shandy - or make repeated use of them in order to obtain the desired effect.

The following are three of the more striking examples of $20^{\text {th }}$-century multilingualism, where foreign languages are highlighted at a novel's very beginning, middle, and end, respectively. What many consider to be Guillermo Cabrera Infante's masterpiece, Three Trapped Tigers (Tres tristes tigres, 1965), opens with a hilarious prologue in a mix of Cuban Spanish and American English wryly evocative of the nightlife in 1950s U.S.-controlled Havana. Before him, Thomas Mann let his character Hans Castorp convey his feelings in awkward French to the Russian émigrée Clawdia Chauchat in a language-infused chapter, ominously entitled "Walpurgisnacht" and conspicuously placed at the centre of The Magic Mountain (Der Zauberberg, 1924). An even more spectacular case of textual multilingualism is Juan Goytisolo's Juan the Landless (Juan sin tierra, 1975). At the end of this daunting novel, Castilian (Spain's dominant language as well as the narrator's) gradually turns into Arabic, the main language spoken on the opposite shore of the Mediterranean. This transformation, a cultural shift as much as a purely linguistic transfer, is completed in three or four stages during the course of which 'standard' European Spanish becomes 'slangy' American 
Spanish (with a Cuban accent), then turns into a North-African Arabic dialect, before taking on the guise of quotes from the Koran's $109^{\text {th }}$ sura, transliterated in Roman letters. The metamorphosis is complete when on the last page Arab verses appear in Goytisolo's own calligraphy. But with Arabic being read from right to left, we have thus not reached the end but rather the beginning of the story. The novel's final words paradoxically become its first words, and the reader can start anew (see Kunz 1993 for a splendid analysis).

As these examples may have made clear, the actual quantity of foreignisms in a text is rather less important than the qualitative role they play within its overall structure, i.e. their potential as functional elements. Instead of dismissing foreign-language samples as mere comic relief, or "as an irrelevant, if not distracting, representational factor" (Sternberg 1981: 224), it might be more rewarding to see if and how they acquire a deeper significance with regard to plot-construction or even become a controlling metaphor governing character discourse and behaviour. Such effects may actually be obtained by using very few foreign elements, enough to distort the image and to require the reader to pay attention.

\section{Multilingualism and translation}

Multilingual writing can be linked to translation in more than one way. First of all, translation is a welcome tool for writers who feel the need to use foreign languages yet do not want to exceed the linguistic competence of their presumably monolingual audience. Translating all or even part of the heterolingual utterances allows them to do just that - to have their cake and eat it too, as it were. In Walter Scott's day, for instance, Latin was still a must for the educated classes. He therefore could let one of his characters, when requested to give his opinion on the outcome of the Jacobite uprising, quote a Roman historian in Latin: "Why, you know, Tacitus saith 'In rebus bellicis maxime dominatur Fortuna', which is equiponderate with our own vernacular adage, 'Luck can maist in the mellee"' (Scott 1985: 335). Scott's decision to append an approximate version as an intratextual gloss (a more literal translation would be: "In matters of war Fortune mostly rules") shows he did not want to alienate his less-educated readers - he was, after all, one of the first to write what we now call bestsellers. At the same time, he was able to establish a particular rapport with those 'happy few' who actually did share his knowledge and love of the Classics. Precisely because of the double reading standard they allow the author to maintain, such translations act as textual buffers against the foreign tongue.

In Scott's novels, Latin quotes also serve another, more oblique purpose. The story of Troy's decay and fall as recounted in Virgil's Aeneid proves to be an essential intertext for his reading of history in Waverley. Looking at the blackened walls of his ransacked residence, the Baron of Bradwardine turns to Edward Waverley and says: "To be sure, we may say 
with Virgilius Maro: Fuimus Troes [We are Trojans no longer] and there's the end of an auld sang" (Scott 1985: 443). He explicitly establishes a connection between Caledonians and Trojans by quoting from the second book of Virgil's epic, where Aeneas, himself a survivor of the fatal battle of Troy, tells Dido the story of his city's downfall. This tale within a tale has thus been lifted from its context by Bradwardine (and hence, by Scott) to lend it exemplary value. The defeat of the Highlanders at Culloden (1746) becomes the stuff that legends are made of, no longer the story of a lost cause. Through intertextuality, its retelling is turned into a process of symbolic compensation whose narrative mould was handed down from Antiquity.

When language is itself one of the topics addressed in a given novel, translations accompanying heterolinguistic utterances may focus less on referential meaning, and highlight more subdued cultural connotations. Thus, in D. H. Lawrence's Women in Love, Ursula Brangwen calls dominant male behaviour "a lust for bullying - a real Wille zur Macht - so base, so petty", to which her lover Rupert Birkin replies:

I agree that the Wille zur Macht is a base and petty thing. But with the Mino, it is the desire to bring this female cat into a pure stable equilibrium, a transcendent and abiding rapport with the single male. Whereas without him, as you see, she is a mere stray, a fluffy sporadic bit of chaos. It is a volonté de pouvoir, if you like, a will to ability, taking pouvoir as a verb. (Lawrence 1960: 167)

By joining versions that have such a different ring in English ("a lust for bullying" and "a will to ability"), yet are supposed to mean the same in German and in French (la volonté de pouvoir is the received French translation of Nietzsche's Wille zur Macht), Birkin's comment becomes metalinguistic in nature, albeit in a stereotypical way: the harsh German sounds suggest violence, while French confirms its well-known penchant for rhetorical niceties, as Ursula stresses in her reply: "Sophistries!".

Intratextual glossing and the creation of intertextual echoes and metalinguistic effects - all of which always involve a careful balancing of the author's quest for textual sophistication and what s/he perceives to be the linguistic skills of his/her prospective public - do not exhaust the range of possible functions of multilingualism and text-internal translation. Thus, interlingual misunderstandings and mistranslations can be used for comic effect too, namely by bringing about what humour theorists would call an incongruity or conflict between different cognitive schemes. This comic technique is at least as old as Shakespeare (Delabastita 2005a) and in the present volume it is touched on by Juliette Taylor in her discussion of Nabokov's Ada, even though the category of the comic fails to register the subtlety of Nabokov's use of mistranslation. Several further uses and functions will be presented in the following two sections. 


\section{Fictional translators}

\subsection{The power of the translator}

In the heyday of structuralism and semiotics translation was often conceptualized in terms of semiotic schemes which could in most cases be reduced to something like this:

Sender $\mathbf{1} \rightarrow$ Text $1 \rightarrow$ Receiver $1=$ TRANSLATOR = Sender $2 \rightarrow$ Text $2 \rightarrow$ Receiver 2

Unfashionable as such diagrams may be today, this remains a powerful representation of what translation is in most typical instances expected to do. The fact that variants and borderline cases are legion does not invalidate this point, nor does the fact that careful contextualisation (who, what, where, when, how, why) will unavoidably reveal a multitude of irreducible historical differences and complications. The variants and the historical specifics may actually become more visible and meaningful through and against the general prototype.

The model visualises the translators' central position and thus evokes the enormous power and responsibility they have in multilingual communication. The survival of a text, the success of a business deal, the future of a refugee, even human lives may depend on how translation is handled. We would venture the hypothesis that the translator's power can be assessed in terms of two variables: the importance of the message that is to be communicated, and the distance between the cultures which enter into communication via the translator. By importance we mean that the translator will have more power and carry a heavier burden of responsibility inasmuch as the text to be translated conveys content or serves a purpose of serious consequence. Needless to say, importance is a relative notion, which needs to be defined in pragmatic terms (e.g. depending on circumstances, the same translation error can have a fatal cost or simply pass unnoticed). By distance we mean the degree of mutual incomprehension and non-communication that would follow if it weren't for the translator's bilingual and bicultural competence and intervention. Incomprehension is a matter of the incommensurability of the languages and cultures involved (knowledge, value and belief systems), but it can be seriously aggravated in cases where the cultural constituencies meeting through translation have radically opposed interests and agendas.

\subsection{Between Gods and humans}

Divine messages (e.g. sacred books) could provide us with an extreme example of the translator's power. What could be more radically different than the spheres of ethereal divine perfection and those of human limitation, error and $\sin$ ? Or what messages could have a more profound significance than those coming from an omnipotent God? Different religions and faiths seem 
to have incorporated a solution to this problem by developing a mythical account of how God had his divine message translated and/or multiplied in a language (or languages) that humans can understand. These are indeed tasks of such magnitude that human translators cannot be trusted to bring them to a happy conclusion without divine assistance. ${ }^{3}$ Stories of divine intervention have thus attached themselves to the genesis of sacred books and their translations. ${ }^{4}$ It is the divine inspiration guiding the fallible human translators that guarantees the absolute equivalence, sacredness and orthodoxy of their work, so much so that believers can safely consider them as originals in their own right (e.g. the Septuagint).

Accounts of the origin or translation of sacred texts therefore constitute an important body of fictions involving translation. But then, precisely what is 'fiction', and where to draw the line between 'fact' and 'fiction'? 'Orthodox' followers will surely believe stories about divinely inspired translation to be literally true and hence firmly deny their imaginary or mythical status; less 'fundamentalist' believers, on the other hand, will acknowledge the fictional status of such stories, yet perhaps still attribute some allegorical or 'deeper' truth to them; whereas sceptics and agnostics will simply see them as fictional projections through and through. Space prevents us from delving more deeply into this issue, but the example should suffice to show that, far from being a context-free or observer-independent reality, fictionality comes in various kinds, shapes and degrees. As we shall see, the issue of fictionality is also at stake, albeit with a different range of implications, in several of the case studies included in this volume, not least in those where the account of translation has a more or less outspoken (auto)biographical dimension. ${ }^{5}$

\subsection{Intergalactic}

One level below (so to speak) the sacred / human interface, we find another body of narratives in which translators potentially have massive power and crushing responsibilities, namely in the realm of science fiction, where storylines often pose problems of communication - hence of translation - on an interplanetary, interstellar or even intergalactic scale. Here too, the intrinsic importance of the messages is huge inasmuch as the very survival of our planet (human race, solar system...) may well be at risk, while the linguistic and cultural distances to be bridged by the translator are of a mind-boggling scale as well, not to mention the difficulty of negotiating the conflicting interests of us, humans, and them, aliens.

In a fascinating discussion of the image of translation in science fiction and astronomy, Brian Mossop (1996: 2) notes that translation is not as much of a central theme in science fiction as one would perhaps have expected: the translation problem is usually "either passed over in silence or dispensed with in one of three ways that reflect received ideas: telepathy, lingua franca and machine translation". Technology and (pseudo)science thereby 
often take the place of divine inspiration as the fictional sleight of hand helping human translators to bridge the unbridgeable without too much inconvenience. The so-called Babelfish in The Hitchhiker's Guide to the Galaxy (an earplug that will automatically render any message heard into the hearer's language) is essentially the 'scientific' and acoustic equivalent of the magic disks through which Joseph Smith, founder of the Mormon Church in 1830, had to read the obscurely worded Book of Mormon in order to have the divine message visually revealed to him in his native English (Hermans 2004).

In other cases, however, the translatability of interstellar messages and extraterrestrial inscriptions does become more of a key issue in the story. For a discussion of the endless semiotic puzzles that this may entail, we refer the reader to Mossop's aforementioned article, to Walter E. Meyers' Aliens and Linguists: Language Study and Science Fiction (1980), or to the fifth chapter entitled "Final Frontiers" in Michael Cronin's Across the Lines: Travel, Language, Translation (2000). Interestingly, as editors of the present volume we have not received a single submission specifically devoted to this type of multilingual or translation-based narrative, despite the huge popularity of sci-fi - and other forms of fantasy - in both literature and visual media. ${ }^{6}$ Possibly this reflects the 'popular' and therefore somewhat dubious status of the genre, but perhaps even more so the current academic fascination with postcolonial and postmodern themes and issues of cultural identity.

\subsection{International, or even intercontinental}

Coming down one more step on the scales of galactic extent and sacred or mythical resonance, to reach a level where stories about multilingualism and translation start referring to chronicled human history in a more tangible manner, we find ourselves dealing with a corpus of narratives which describe and fictionalise the encounters and struggles between continents and peoples. Many of them can be subsumed under the labels of colonial and postcolonial writing. They are typically stories in which explorers and settlers in the crucial first stages of the colonisation process (or administrators, in the later stages of established colonial relations) have to use the services of translators, often local ones (see also Remael \& Logie 2003).

In these stories too, translators make enormous scores for power and responsibility, if one takes into account both their control over flows of information which may determine the fate of entire communities, and the sheer linguistic and cultural gap to be negotiated (not to mention the opposed agendas of indigenous populations and colonisers). Interlinguistic and intercultural mediation in colonial settings has not surprisingly generated a lot of historical and fictional narratives, some of which have gone on to lead a life of their own. Consider the cases discussed by Victoria Ríos-Castaño and Ilse Logie (the interpreters of the conquistadores in Central and South 
America), as well as by Katrien Lievois and Raymond Mopoho (the local interpreters in Africa's French-speaking colonies). A Canadian example would be the early-17 $17^{\text {th }}$-century trapper Étienne Brûlé, sent by Samuel de Champlain, governor of New France, to live with the Hurons and learn their language in order to further the French cause. Brûlé instead changed allegiances and 'went Indian'. After assimilating into Huron society for twenty years, he was not rewarded for his efforts, however, but assassinated by his hosts. Notwithstanding the difference of space and time, this is precisely the tragic fate that befalls the male hero in the travel story by Kristien Hemmerechts discussed here by Hildegard Vermeiren. A morbid detail of great symbolical significance is that Brûlé's tongue was cut out and ceremonially eaten (Stratford 1991: 97).

\subsection{Subjective experience}

The translator's power to 'make a difference' can have momentous, perhaps even heroic, and therefore potentially tragic dimensions, as is likely to be the case in the kinds of stories surveyed in the preceding three subsections. But not all fictional translators are protagonists at a turning point in real or imagined history, willy-nilly holding the lever of change. In many narratives, the translator's agency and impact on history will have the more modest dimensions that would correspond to the endeavours of 'ordinary' people in 'real' life, going about their everyday business in a multilingual environment and trying to do as well as character and circumstances permit. Stories involving the multilingual encounters and experiences of individual travellers, immigrants, nomads, expatriates, explorers, refugees, exiles, and the like (involving changes of geographical space) would typically fall into this fourth category, and so do the growing body of stories set in multicultural, cosmopolitan settings (where interlingual and intercultural contact is bound to occur regardless of changes of place). Not all, but many of these stories take place at the margin of 'official' or 'canonised' culture, involving outsiders, subcultures and minority groups (Gentzler 2002).

It is this fourth category of narratives which is best represented in the studies brought together in this volume: see especially the fictional materials discussed by Carolina Amador Moreno, Brian J. Baer, Beverley Curran, Tessa Dwyer, Iulia Mihalache, Hildegard Vermeiren and Judy Wakabayashi. Their success and topicality is to be linked with a range of factors which may be subsumed under the umbrella term of globalisation - growing physical and intellectual mobility; the internationalisation of trade, industry, media, communication, politics, terrorism, and warfare; migration and the growth of cosmopolitan centres around the world; the rapid spread of English as the world's lingua franca; colonial and postcolonial relations - and the resistance, bewilderment and anxieties that these processes seem to be engendering in many quarters, all the more so since our grand utopian narratives - religion, democracy, liberty, reason, 
progress - have for many of us stopped providing all the reassuring answers. Like (and often along with) 'travel', 'translation' has thus become a master metaphor ${ }^{7}$ epitomizing our present condition humaine, evoking our search for a sense of self and belonging in a perplexing context of change and difference.

In these stories, multilingualism and translation are described in terms of subjective experience and personal identity rather than in the larger perspective of human history. History is of course present in a more or less prominent manner, always conditioning individual agency and experience, but the translator is not presented as being in a position to actually change its course. Even though their ethical pitch may therefore seem to be much lower than in narratives where larger issues are at stake, the difference is surely one of degree and not of kind: every translation act involves ethics. Conversely, the importance of subjective perception and experience is not restricted to anonymous translators whose actions have not seen the limelight of history and myth-making. Let us therefore make abstraction of the scale and range of their operation when we try to sum up the main affective components of their subjective experience:

- trust: the interlocutors involved who do not know the 'other' language lay their fate entirely in the hands of the translator, unavoidably running the risk of meanings and communicative intentions being distorted or even consciously subverted in the process; if such trust is missing, how to deal with marginalisation and ostracism?

- loyalty versus betrayal: how to balance the conflicting loyalties that the translator may have or develop towards the sender of the original and/or the ultimate receivers, especially if the interlocutors have conflicting interests?; in other words, how to avoid betraying one of either parties?; and how to resist the temptation of deceit and manipulation for personal gain?

- invisibility and authorial ambition: when public or social recognition of the translator's work is not forthcoming, as is very often the case, how to avoid frustration and how to control the ambition to become an original author oneself?

- untranslatability: given the many pressures under which the translator is working, how can meanings preserve their identity and stability, or how could translation ever be unproblematic or straightforward?

- trauma: how to live with the crushing weight of other people's traumatic experiences that the translator may have to absorb and express in his/her own words?

- identity: how can translators prevent the permanent position-shifting (the oscillations of empathy and sympathy, the never-ending switching and adjusting to other parties, the make-believe of speaking/writing for others) from 'eroding' or 'dislocating' their sense of self, leaving them unanchored and alienated in a space 'in-between'?

These and other issues may or may not be brought into play in fictional representations. The more they are, the more the focus is drawn from the 'objective' reality of the translator's impact to the subjective, emotional 
and experiential dimension of how the process affects individuals and communities.

\section{Narratological perspectives}

\subsection{Such stuff as stories are made on}

We would like to reflect briefly on the idea that our theme could be approached from the angle of narratology too. It seems worthwhile to raise the question if it would be possible to construct a 'grammar' or a 'matrix' of typical multilingual or translation-based plots. Without committing ourselves to a firmly affirmative answer to this question, and not having the space to develop the theme in its daunting complexity, we do want to suggest that the use of multilingualism and interlinguistic situations is perfectly consistent with a number of basic narrative principles, such as conflict, character configuration, spatial opposition, mimesis, and suspense management. In other words, the 'emplotment' of multilingualism and translation definitely belongs to the intrinsic potentialities of the narrative genre.

From time immemorial literary critics have agreed on the importance of conflict for the construction of narratives. Different individuals and groups have different - conflicting - wants and needs and this tension is what motivates most of the central action. This struggle divides the different actors in the story, with the protagonist or hero finding him/herself opposed to the antagonist, and with either party usually being able to count on helpers. Narratologists developing highly complex models to account for character configuration and plot construction have all somehow elaborated on the conflict principle. In stories describing cosmopolitan settings (borderlands, modern cities, the world of international business, politics, diplomacy and espionage...), or in stories in which changes along the spatial axis play a crucial role (travel, exploration, conquest, migration...), conflicts are likely to find expression on the linguistic plane as well. Translation - interlinguistic mediation - may then play an instrumental part in their resolution, or, alternatively, the absence or mismanagement of interlinguistic mediation, deliberate or not, may become the main obstacle to a solution. Independently of all symbolical and sociocultural value that translation may acquire, the translator in a story can in this way be central to the 'mechanics' of the plot in a number of ways: as protagonist, antagonist and/or helper, possibly in shifting roles (for, after all, the translator-as-helper may turn out to become the protagonist, or an antagonist, etc.).

As a simple example we might consider the way in which the strongly 'Hollywoodised' film version of Nathaniel Hawthorne's classic adultery novel The Scarlet Letter rewrites the role of the Reverend Arthur Dimmesdale, the secret father of Hester's illegal child. The original novel gives little attention to the native Americans with which the young seaside 
Puritan community of New England settlers share the region in a very uneasy relationship, but the film version gives them many crucial scenes, including the story's final climax in which Dimmesdale and a group of local women accused of witchcraft are saved from collective hanging by a spectacular eleventh-hour rescue operation staged by the friendly Indians. This finale, which is almost a replica of the ending of Kevin Costner's Robin Hood, could hardly have been further removed from the conclusion of the original novel, which presents a final scene of guilt, repentance and reconciliation in the face of death, rather than touch-and-go escape and romance. It is crucial to note that Dimmesdale is a Bible translator in the film, rendering the Scriptures into Algonquian. His linguistic skills make him into a trusted friend of the Indians - indeed the only white man they can believe. As a translator he is the local bridge-builder between cultures and communities. There is much ideological ambivalence in the manner in which the film allies Dimmesdale, the male hero of the story, with the film's alleged feminist and postcolonial agendas, but the point is that none of this could have happened without the film's pseudo-anthropological interest in translation. Clearly, the radical overhaul of the novel's ending and ideology hinges on the role of Dimmesdale as a Bible translator, who straddles races, languages and cultures, and is thus able to win the Indians over to his side as helpers in his double struggle with rigid Puritanism and with Hester's evil husband (opponents), so that Hester and Dimmesdale (protagonists), the pair of starcrossed lovers, can finally achieve what is their due: the free expression and enjoyment of their love.

By the same token, translation can be employed for the sake of mystery and suspense-management. The art of narrative largely depends on the manipulation of the reader's knowledge and curiosity. From Sherlock Holmes's adventure with “the Greek interpreter" (1893) to Dan Brown's Da Vinci Code (2003) one finds countless examples of popular fiction where translation is used to encode and then at the appropriate moment unlock a crucial piece of information, such as a prophecy or a secret message. Consider, in this collection, the Russian detective stories presented by Brian J. Baer.

\subsection{From story content to textual representation}

Our examples so far belong to the (intra)diegetic level, i.e. the level of the fictional world represented by the text. But narratological theory also enables us to model very different ways of fictionalising multilingualism and translation, namely those whereby the fictional translator operates not within the story but at the (extradiegetic, metadiegetic, metanarrative) level of the story's telling.

This is where we might situate the well-known device of the pseudotranslation (discussed by Christine Lombez in this volume, as well as by Judy Wakabayshi). Authors may have recourse to this device for the sake 
of literary mystification, i.e. in order to mislead the reader as to the true genesis or status of the text s/he is reading. In many cases, however, the smokescreen is meant to be transparent or semi-transparent from the beginning, and the fiction of the translated origin of the text has a more playful character. In whichever variety, the phenomenon of pseudo-translation appears to be much older and more widespread than traditional literary history has led us to believe.

Modern fiction has shown a growing fascination with the very process of textual representation, which may be traced back to the crisis of literary realism and the beginning of modernist aesthetics around the turn of the century. Recall Henry James's short story “The Real Thing” (1892), whose narrator-artist confesses his "innate preference for the represented subject over the real one: the defect of the real one was so apt to be a lack of representation" (1543-1544). The narrative conventions of 'realist' representation came increasingly under pressure, as writing became something of a self-conscious or even narcissistic process, permanently aware of itself and of the reader reading it. Metafiction is the term usually used to describe the growing class of fictions which highlight and question their own artificiality as representations of the world, with self-reference prevailing over mimetic reference. Different techniques can achieve such an effect: the use of a very overt narrator; the juxtaposition of different styles and text-types; parody, pastiche and other forms of intertextuality; the mixing up of different communicative levels (e.g. author vs. narrator, narrator $v s$. character); mise en abyme (e.g. novel-within-a-novel) and other mirroring techniques; and, indeed, the use of different languages. The crisis of representation has enabled metafictional narrative modes to occupy an increasingly central position in the literary system, and these very same circumstances have provided the perfect hotbed for narratives staging translation and its attendant questions of fidelity, truth, directness, originality, and its opposites unfaithfulness, manipulation, mediation, dependence.

Not surprisingly, in metafictional writing by the likes of Borges, Cortázar, Nabokov and Calvino translation is the object of much speculation, whether in earnest or in jest (Thieme 1995; Kristal 2002). Metafictional elements are clearly present in the novels discussed by Marella FeltrinMorris, Judy Wakabayashi and Juliette Taylor (in this volume). Another interesting example is given by Andrew Chesterman in his Memes of Translation (1997: 112), where he presents the case of

a recent postmodern Russian novel by Jevgeni Popov, translated into Finnish [...] by Jukka Mallinen, himself a well-known literary figure in St. Petersburg circles. At one point in the novel, the hero travels from Russia to Helsinki, which is portrayed as a haven of peace and opportunity and personified in the figure of one "Uncle Jukka". The point is that this Uncle Jukka is without a doubt Jukka Mallinen, the translator, whom Popov has thus incorporated as a character in the very novel which Mallinen will translate. To many of the original Russian readers, this postmodern role-play is presumably absent; but to Finnish readers the translator is most obviously "present", "visible". 
With the Finnish translator here entering the fictional world of the novel waiting to be translated by him, narrative and meta-narrative levels get entangled here in a typical metafictional manner which is reminiscent of how the omniscient narrator in the famous $55^{\text {th }}$ chapter of John Fowles's The French Lieutenant's Woman (1969) suddenly leaves his late-1960s narrative present to leap a century back and emerge in a different ontological framework, sitting opposite his male protagonist Charles in a train travelling to Victorian London.

\section{Translating multilingualism}

The translation of multilingual texts - whether they involve translation or not - always presents a unique challenge (Grutman 1998; forthcoming). It involves the reconfiguration of multilingual relations obtaining within source texts, but the significance of these relations is deeply rooted in the source culture by the way in which they represent or transform multilingual relations existing in social reality. Let us take a glimpse at what happened to Lawrence's Women in Love in French translation. Here is the passage quoted before, now in French:

Je suis d'accord que la volonté de puissance est quelque chose de vil et de mesquin. Mais avec Minou, c'est le désir d'amener cette femelle à un équilibre stable et parfait, à un rapport transcendant et durable avec le mâle célibataire. Tandis que sans lui, comme vous voyez, elle est un simple fragment égaré, une parcelle ébouriffée et sporadique du chaos. C'est une volonté de pouvoir, si vous voulez, en prenant "pouvoir" pour un verbe. (Lawrence 1974: 210)

All traces of foreignness have been conveniently erased by Maurice Rancès and Georges Limbour. Gone are Nietzsche's German and the pseudo-philosophical gist of the conversation. Gone, as well, is the exotic French language - the preferred idiom for love and intellectual conversation. Moreover, the stylistic contrast between French and English, explicitly commented upon by Ursula Brangwen, has been almost completely neutralized, were it not for a footnote mentioning that the second "pouvoir" (set apart in the text by quotation marks and italics) already figured in French in the original. But so did "rapport" and the earlier "volonté de pouvoir", which go undocumented: a clear sign of "incoherence" (Berman 1999: 63).

Another example would be the Dutch translation of the bilingual scenes in Shakespeare's Henry V, where it may be decided to preserve the passages in French untranslated, or to replace instances of English-French linguistic interference by instances of Dutch-French interference. However, the effect of all this is bound to be completely different inasmuch as the social history of French in the Low Countries has left behind a totally different associative and ideological residue (Delabastita 2005b). Similarly, the translation of dialects or sociolects (see Lane-Mercier 1997 for a useful dis- 
cussion) may or may not be successful in mimicking certain linguistic features (e.g. phonetic ones), but the social history associated with the use of particular dialects - by specific characters at certain points in place and in time - will, again, in most cases be impossible to reproduce.

Because of such 'technical' translation problems - but also because it flies in the face of many perceived notions of language, culture and identity, to start with - linguistic diversity is usually at considerable risk of disappearing or having its subversive potential downplayed in translation.

While translation of multilingual texts ${ }^{8}$ is not a central feature of this special issue, it is touched upon in a number of articles. Roberto A. Valdeón, for example, not only examines the uses of Spanish and French in the American sitcom Frasier, but also the curious complications that arise in the Spanish and French dubbed renderings of its multilingual sequences. Hildegard Vermeiren teases out the translation problems that would be generated by a travel story, were it to be rendered into any of the three foreign languages which are mobilised within the narrative's fictional world. Vermeiren's analysis shows how non-metafictional stories can unexpectedly throw up irresolvable paradoxes in translation and acquire a metafictional dimension in the process.

\section{Conclusion: a 'fictional turn in translation studies'?}

The papers and the abundant and recent primary and secondary bibliographical material collected between the covers of this volume might be seen as adding further evidence to the case that something like a 'fictional turn' (the term is Else Vieira's; see Pagano 2000) is taking place in translation studies, adding another bend to the already sinuous history of the discipline, which has recently been through the pragmatic turn, the birth of the interdiscipline, the cultural turn, the cognitive twist, the return to ethics, the return to linguistics, and possibly a few more twists and turns we have been too dizzy to notice. Perhaps such metaphors smack too much of academic marketing and display somewhat too relaxed an approach to the complexities of a serious historiography of scholarly disciplines. But there is no denying that there has been a growing number of fictional representations of translation and multilingualism, as well as an upsurge in their study.

At the object-level, one cannot help being struck by an increase of fictional materials that have explicitly multilingual and multicultural settings and that involve translation scenes. In that respect, it is no coincidence that a year after the resounding success of Lost in Translation, Hollywood brought out The Interpreter, hoping to cash in a second time on the translation theme. This trend is to be linked with a range of factors we have referred to in the preceding pages, including globalisation, postcolonialism, our search for identities, the crisis of representation, the taste for metafictional effects, and so on. 
But things favouring the study of our theme have been happening at the meta-level too, i.e. the level where cultural critics and researchers locate themselves. Since the 1970 s at least, many translation scholars have gradually come to see translation as a cultural and historical phenomenon and have therefore rediscovered the interest of older and 'pre-scientific' discourses on translation. Witness the publication of anthologies and discussions of historical statements on translation offered by Hans-Joachim Störig (Das Problem des Übersetzens), André Lefevere (Translating Literature: The German Tradition from Luther to Rosenzweig), Douglas Robinson (Western Translation Theory from Herodotos to Nietzsche), Lieven D'hulst (Cent ans de théorie française de la traduction), and several more. However, most of the texts sampled in these collections are non-fictional and non-narrative pieces (e.g. essays involving description, exposition, argumentation, instruction, philosophical speculation, etc.). The current trend of studying fictional representations of translation could be construed as a perfectly logical extension of this type of study. The underlying argument remains the same - in our study of historical concepts and practices of translation, statements about translation are no less valid documents worthy of research than the translations themselves - but it is simply spilling over from text-types that are not primarily narrative or not fictional, into those that are.

Yet other, even more profound changes have caused the very distinction between object-level and meta-level to be much less secure than before. With the postmodern critique of Western rationality and empirical scholarship, more and more attention is now given to the singularity of cultural events (as opposed to what is seen as the descriptive scholar's futile search for general rules and systems), to concrete, lived, personal experience, including its various emotional, unconscious and psychosomatic aspects (as opposed to what are seen as the timeless and lifeless abstractions of rationalistic science), and to the ethical or even explicitly political significance of events and experiences (as opposed to the 'neutral' scientific understanding of the world). Even in its most unabashedly 'unscientific' forms (fiction, autobiography, the anecdote), narrative can then become the perfect medium to 'explore' (a term which is preferred to 'describe', 'investigate', 'examine' or 'analyse') the multiple levels of these singular experiences. Why should we have qualms about seeing translators, as well as the stories by and about them, as holders of deeper truths about translation? We might want to recall here the familiar argument that one single fictional masterpiece can tell us a great deal more about a society than a library full of learned non-fictional historical and sociological tomes, but the point is precisely that the whole premise of such comparisons is now believed to be flawed: "the very borderline between fiction and nonfiction has become more and more blurred" (Pagano 2002: 97). Wim Tigges (1999: passim) tells us that Brian Friel was inspired by George Steiner's celebrated After Babel when he wrote his play Translations (1981). Well then, if translation scholars in their turn tap fiction as sources of knowledge and understanding, might we not be travelling towards the point where the distinction between translation and translation 
studies - or between fiction and fiction studies, for that matter - appears to have been an illusion all along?

One may subscribe to such notions, or just smile at them. But that the study of fictional representations of multilingualism and translation is a problem of irresistible intellectual interest and great historical relevance is at least one point that all will agree on. And if such a consensus does not exist, it is our hope that the following papers will at least make a small contribution to it.

\section{Bibliography}

\section{Primary texts}

Adams, Douglas (1979). The Hitch-Hikers Guide to the Galaxy. London: Pan. Brown, Dan (2003). The Da Vinci Code. New York: Doubleday Books.

Cabrera Infante, Guillermo (1971 [1965]). Three Trapped Tigers (tr. Donald Gardner \& Suzanne Jill Levine, in collaboration with the author). New York: Harper and Row.

Doyle, Arthur Conan (1893). "The Greek Interpreter". Strand Magazine. September 1893.

Fowles, John (1969). The French Lieutenant's Woman. London: Cape.

Friel, Brian (1981). Translations. A Play. London/Boston: Faber \& Faber.

Goytisolo, Juan (1977 [1975]). Juan the Landless (tr. Helen R. Lane). New York: Viking Press.

James, Henry (2003 [1892]). "The Real Thing". Nina Baym (ed.). The Norton Anthology of American Literature. Shorter $6^{\text {th }}$ edition. New York/London: Norton, 1539-1556.

Lawrence, D.H. (1960 [1921]). Women in Love. Harmondsworth: Penguin.

Lawrence, D.H. (1974 [1949]). Femmes amoureuses (tr. Maurice Rancès \& Georges Limbour). Paris: Gallimard.

Mann, Thomas (1995 [1924]). The Magic Mountain (tr. John E. Woods). New York: Knopf.

Scott, Walter (1985 [1814]). Waverley (ed. Andrew Hook). Harmondsworth: Penguin.

Sterne, Laurence (1759-1767). The Life and Opinions of Tristram Shandy. York/London.

Tolstoy, Leo (1968 [1863-1869]) War and Peace (tr. Ann Dunnigan). Harmondsworth: Penguin.

\section{Secondary texts}

Appel, Anne Milano (2002). "Extremes of 'Remembering': Translation as 'Figura'”. Tradurre 3(1). On line at: www.biblit.it/ExtremesofRemembering.pdf (consulted 27.09.2005).

Baetens Beardsmore, Hugo (1978). "Polyglot Literature and Linguistic Fiction". International Journal of the Sociology of Language 15, 91-102.

Barnett, Ian (2004). "The Translator as Hero". On line at: www.biblit.it/translator_hero.pdf (consulted 4/10/2004).

Bassnett, Susan \& André Lefevere (eds) (1990). Translation, History and Culture. London: Pinter. 
Berman, Antoine (1999). La traduction et la lettre ou l'auberge du lointain. Paris: Seuil.

Brisset, Annie (1996 [1990]). A Sociocritique of Translation: Theatre and Alterity in Quebec, 1968-1988 (tr. Rosalind \& Roger Gannon). Toronto: University of Toronto Press.

Brittan, Alice (2002). "B-b-british Objects: Possession, Naming, and Translation in David Malouf's Remembering Babylon". PMLA 117(5), 1158-1171.

Brugnolo, Furio \& Vincenzo Orioles (eds) (2002). Eteroglossia e plurilinguismo letterario. Vol. 2. Plurilinguismo e letteratura. Rome: Il Calamo.

Canonica, Elvezio \& Ernst Rudin (eds) (1993). Literatura y bilingüismo. Homenaje a Pere Ramírez. Kassel: Reichenberger.

Chesterman, Andrew (1997). Memes of Translation. Amsterdam/Philadelphia: John Benjamins.

Coseriu, Eugenio (1978). "Falsche und richtige Fragestellungen in der Übersetzungstheorie". Grähs, Korlén \& Malmberg (1978), 17-32.

Cronin, Michael (2000). Across the Lines: Travel, Language, Translation. Cork: Cork UP.

Cronin, Michael (2002). "The Empire Talks Back: Orality, Heteronomy, and the Cultural Turn in Interpretation Studies". Maria Tymoczko \& Edwin Gentzler (eds). Translation and Power. Amherst/Boston: University of Massachusetts Press, 45-62.

Cronin. Michael (2003). Translation and Globalization. London/New York: Routledge.

D'hulst, Lieven (1990). Cent ans de théorie française de la traduction. De Batteux à Littré (1748-1847). Lille : Presses Universitaires de Lille.

Dasenbrock, Reed Way (1987). "Intelligibility and Meaningfulness in Multicultural Literature in English". PMLA 102(1), 10-19.

Delabastita, Dirk (2002). "A Great Feast of Languages: Shakespeare's Bilingual Comedy in King Henry V and the French Translators". The Translator 8(2), 303-340.

Delabastita, Dirk (2004). "If I Know the Letters and the Language: Translation as a Dramatic Device in Shakespeare's Plays". Ton Hoenselaars (ed.). Shakespeare and the Language of Translation. London: The Arden Shakespeare / Thomson Learning, 31-52.

Delabastita, Dirk (2005a). "Cross-Language Comedy in Shakespeare". Humor 18(2), 161-184.

Delabastita, Dirk (2005b). "Henry V in the Low Countries: English, Dutch and the Other Languages". Shakespeare Yearbook 15, 233-250.

Denison, Norman (1978). "On Plurilingualism and Translation". Grähs, Korlén \& Malmberg (1978), 313-319 (discussion 331-351).

Forster, Leonard (1970). The Poet's Tongues. Multilingualism in Literature. London: Cambridge UP.

Franssen, Paul (1999). "The Bard, the Bible, and the Desert Island". Paul Franssen \& Ton Hoenselaars (eds). The Author as Character: Representing Historical Writers in Western Literature. Madison: Fairleigh Dickinson UP, 106-117.

Gentzler, Edwin (2002). "What's Different about Translation in the Americas?" CTIS Occasional Papers 2, 7-17.

Grähs, Lillebill, Gustav Korlén \& Bertil Malmberg (eds) (1978). Theory and Practice of Translation (Nobel Symposium, Stockholm, 6-10 September 1976). Bern/Frankfurt/Las Vegas: Peter Lang.

Grutman, Rainier (1993). "Mono versus Stereo: Bilingualism's Double Face". Visible Language 27(1-2), 206-227. 
Grutman, Rainier (1994). "Honoré Beaugrand traducteur de lui-même". Ellipse 51, 45-53.

Grutman, Rainier (1997). Des langues qui résonnent. L'hétérolinguisme au XIXe siècle québécois. Montréal: Fides/CÉTUQ.

Grutman, Rainier (1998). "Multilingualism and Translation". Mona Baker (ed.). Routledge Encyclopedia of Translation Studies. London/New York: Routledge, 157-160.

Grutman, Rainier (2002). "Les motivations de l'hétérolinguisme: réalisme, composition, esthétique". Brugnolo \& Orioles (2002), 329-349.

Grutman, Rainier (forthcoming). "Refraction and Recognition: Literary Multilingualism in Translation". Target.

Guillén, Claudio (1985). Entre lo uno y lo diverso. Introducción a la literatura comparada. Barcelona: Editorial Crítica.

Hermans, Theo (2001). "Schizofreen lezen". Filter 8(2), 8-15.

Hermans, Theo (2004). "Vertalen als navelstaren. Van equivalentie naar intertekstualiteit". Filter 11(4), 3-18.

Hoenselaars, Ton \& Marius Buning (eds) (1999). English Literature and the Other Languages. Amsterdam/Atlanta, GA: Rodopi.

Hoenselaars, Ton (1999). "English Literature and the Other Languages: A Select Bibliography". Hoenselaars \& Buning (1999), 343-386.

Horn, András (1981). "Ästhetische Funktionen der Sprachmischung in der Literatur". Arcadia 16, 225-241.

Koster, Cees (1997). "Treinen spotten. 'Kut. Fuck. Klote. Shit': het Engels in het Nederlands". Filter 4(1), 40-46. On-line at: http://www.tijdschrift-filter.nl/.

Kristal, Efraín (2002). Invisible Work. Borges and Translation. Nashville: Vanderbilt UP.

Kunz, Marco (1993). "El final bilingüe de Juan sin Tierra de Juan Goytisolo". Canonica \& Rudin (1993), 241-252.

Kunz, Marco (1998). "La variedad lingüística y su traducción: sobre un pasaje de Juan Goytisolo". Maria Antonietta Terzoli (ed.). Colloquium zu Ehren von Germán Colón (Acta Romanica Basiliensia 9). Basel: Romanisches Seminar, 35-46.

Lane-Mercier, Gillian (1997). "Translating the Untranslatable: The Translator's Aesthetic, Ideological and Political Responsibility". Target 9(1), 43-68.

Lefevere, André (1995). "The Word in Two Languages: on Translating Hybrid Texts". Henri Bloemen, Erik Hertog \& Winibert Segers (eds). Letterlijkheid Woordelijkheid. Literality Verbality. Antwerpen/Harmelen: Fantom, 223-233.

Lefevere, André (ed.) (1977). Translating Literature: The German Tradition from Luther to Rosenzweig. Assen/Amsterdam: Van Gorcum.

Levy, Lital (2003). "Exchanging Words: Thematization of Translation in Arabic Writing from Israel". Comparative Studies of South Asia, Africa and the Middle East 23(1-2), 106-127.

Logie, Ilse (2003). "Plurilinguismo y traducción en la obra de Julio Cortázar". Ciberletras: revista de crítica literaria y de cultura / Journal of Literary Criticism and Culture 10. On line at: http: //www.lehman.cuny.edu/ciberletras/v10/logie.htm).

Logie, Ilse (2004). “La Malinche, Jerónimo de Aguilar, Felipillo". Filter 11(1), 3-10.

Lyons, John (1980). "Pronouns of Address in Anna Karenina: the Stylistics of Bilingualism and the Impossibility of Translation". Sidney Greenbaum, Geoffrey Leech \& Jan Svartvik (eds). Studies in English Linguistics for Randolph Quirk. London: Longman, 235-249.

Malmberg, Bertil (1978). "Introduction au colloque”. Grähs, Korlén \& Malmberg (1978), 11-15. 
Martín Ruano, M. Rosario (2003). "Bringing the Other Back Home: the Translation of (Un)familiar Hybridity”. Linguistica Antverpiensia (New Series) 2, 191-204.

Meyers, Walter (1980). Aliens and Linguists. Athens, Georgia: University of Georgia Press.

Meylaerts, Reine (2004). L'aventure flamande de la Revue belge. Langues, littératures et cultures dans l'entre-deux-guerres. Brussels/Frankfurt: Presses Interuniversitaires Européennes/Peter Lang.

Mezei, Kathy (1988). "Speaking White: Literary Translation as a Vehicle of Assimilation in Quebec". Canadian Literature 117, 11-23.

Mezei, Kathy (1998). "Bilingualism and Translation in/of Michele Lalonde's Speak White". The Translator 4(2): 229-247.

Moretti, Franco (1998 [1997]). Atlas of the European Novel. London/New York: Verso.

Mossop, Brian (1996). "The Image of Translation in Science Fiction \& Astronomy". The Translator 2(1), 1-26.

Pagano, Adriana S. (2000). "Sources for Translation Theory: Fiction in Latin America". ATA Chronicle 29(4), 38-44.

Pagano, Adriana S. (2002). "Translation as Testimony: On Official Histories and Subversive Pedagogies in Cortázar". Maria Tymoczko \& Edwin Gentzler (eds). Translation and Power. Amherst/Boston: University of Massachusetts Press, 80-98.

Polezzi, Loredana (ed.) (forthcoming [2006]). Translation, Travel, Migration. Special issue of The Translator 12(2).

Raillard, Edmond (1995). "Atelier de catalan". Onzièmes Assises de la traduction littéraire. Arles: Actes Sud, 73-75.

Remael, Aline \& Ilse Logie (eds) (2003). Translation as Creation : the Postcolonial Influence. Antwerpen: Hogeschool Antwerpen, Hoger Instituut voor Vertalers en Tolken. Special issue of Linguistica Antverpiensia (New Series) 2.

Robinson, Douglas (ed.) (1997). Western Translation Theory from Herodotus to Nietzsche. Manchester: St Jerome.

Sarkonak, Ralph \& Richard Hodgson (1993). "Seeing in Depth: the Practise of Bilingual Writing”. Visible Language 27(1-2): 6-39.

Serrano, Richard (2000). "Translation and the Interlingual Text in the Novels of Rachid Boudjedra". Mildred Mortimer (ed.). Maghrebian Mosaic: A Literature in Transition. Boulder, CO: Lynne Rienner, 27-40.

Smecca, Paola Daniela (2005). Representational Tactics in Travel Writing: A Focus on Sicily. Roma: Carocci.

Stavans, Ilan (2003). Spanglish. The Making of a New American Language. New York: Harper Collins.

Sternberg, Meir (1981). "Polylingualism as Reality and Translation as Mimesis". Poetics Today 2(4), 221-239.

Störig, Hans-Joachim (ed.) (1963). Das Problem des Übersetzens. Darmstadt: Wissenschaftliche Buchgesellschaft.

Stratford, Philip (1991). "Translation". W. H. New (ed.). Literary History of Canada. Canadian Literature in English. $2^{\text {nd }}$ ed. Vol. 4. Toronto: University of Toronto Press, 97-107.

Strümper-Krobb, Sabine (2003). "The Translator in Fiction". Language and Intercultural Communication 3(2) [special issue: Moving Between Worlds: the Transcultured Self in the Sphere of Creative Practice, ed. Alice Tomic \& Evelyne Glaser], 115-121. 
Thieme, Jon (1995). "The Translator as Hero in Postmodern Fiction". Translation and Literature 4(2), 207-218.

Tigges, Wim (1999) “'Confusion is not an ignoble condition': Other Languages in Brian Friel's Translations". Hoenselaars \& Buning (1999), 197-210.

Vidal, Bernard. 1991. "Plurilinguisme et traduction - Le vernaculaire noir américain: enjeux, réalité, réception à propos de The Sound and the Fury". TTR: Traduction, Terminologie, Rédaction 4(2), 151-188.

Wahl, Chris (2005). "Discovering a Genre: The Polyglot Film". Cinemascope 1 (Winter). On line at: www.cinema-scope.net (consulted 03.02.2005).

Wallmach, Kim (2002). "'Seizing the surge of language by its soft, bare skull': Simultaneous Interpreting, the Truth Commission and Country of My Skull". Current Writing. Text and Reception in Southern Africa 14(2), 64-82.

Wilss, Wolfram (1978). "Methodische Problemen der Übersetzungswissenschaft". Grähs, Korlén \& Malmberg (1978), 51-64 (discussion 65-67).

1 See, for example, the wealth of material collected in Hoenselaars \& Buning (1999), or Remael \& Logie (2003).

2 In much of what follows, the term 'translation' will be used in a broad sense that covers 'interpreting' as well.

3 On the imperfection of human language(s), see the biblical story of the tower of Babel (Genesis 11: 1-9).

${ }^{4}$ It might be interesting to note that William Shakespeare - a man who is sometimes, especially in the English-speaking world, regarded as the closest thing to godly perfection that humanity has ever produced - has in certain (pseudo)biographical accounts been fictionalised into a member of the team that produced England's 'national' Bible translation, the 1611 Authorized Version (Franssen 1999). 5 See also Wallmach (2002) which looks into the 'truth' of accounts of the role of interpreting in South Africa's Truth and Reconciliation Commission. With thanks to Erik Hertog for drawing our attention to this article.

${ }^{6}$ Nor, incidentally, did we receive a single submission dealing with myths of sacred translation (a sign of the secularised times?).

7 Research on travel and its multiple links with translation is experiencing something like a boom. See Cronin (2000, 2003), Smecca (2005) and Polezzi (forthcoming), among others.

8 In recent years, scholars from different cultural and scientific backgrounds have become increasingly aware of this particular problem, and we gladly refer the interested reader to their publications. An incomplete list would include: Berman (1999), Delabastita (2002), Grutman (1994), Hermans (2001), Koster (1997), Kunz (1998), Lefevere (1995), Levy (2003), Logie (2003), Lyons (1980), Martín Ruano (2003), Meylaerts (2004), Mezei (1988, 1998), Raillard (1995), and Serrano (2000). The translation studies journal Target is currently preparing a special issue on this very topic (Literary Heteroglossia in/and Translation, guest-edited by Reine Meylaerts). 